\title{
Evaluating the effect of wood ultrastructural changes from mechanical treatment on kinetics of monomeric sugars and chemicals production in acid bisulfite treatment
}

Yalan Liu ${ }^{\mathrm{a}}$, Jinwu Wang ${ }^{\mathrm{b}}$, Michael P. Wolcott ${ }^{\mathrm{a}}$

\begin{abstract}
Currently, various chemical-mechanical treatments were widely used in biofuel production to achieve high total sugar yields. However, the interaction between two treatments was scarcely investigated. In this study, we employed a ball milling process to create ultrastructural changes for Douglas-fir (Pseudotsuga menziesii) micronized wood powders. The 0, 30, and 60 min ball milled wood powders resulted in a crystallinity index of $0.41,0.21$, and 0.10 respectively. It was found that the ultrastructural changes accelerate monomeric sugars production without influencing the yield of sugar degradation products. The optimal acid bisulfite treatment time was substantially decreased from $120 \mathrm{~min}$ to $40 \mathrm{~min}$ as the cellulose crystallinity decreased. Meanwhile, total sugar yield increased from $65 \%$ to $92 \%$ and had a linear relation with a decrease of the cellulose crystallinity.
\end{abstract}


1 Keywords: Crystallinity, Kinetics, Monomeric sugar, Lignosulfonates, Sugar degradation,

2 Enzymatic hydrolysis

\section{Introduction}

5 Lignocellulosic materials are abundant and renewable resources on the earth. Their utilization for

6 biofuel production has drawn substantial attentions due to fossil fuel crisis and environmental

7 pollution (Himmel et al., 2007). However, the intrinsic structure of this material: crystalline

8 structure of cellulose, surrounding by hemicellulose and lignin, inhibits total sugar yield from

9 bioconversion process (Jeoh et al., 2007; Kumar \& Wyman, 2014; Rowell et al., 2005).

10 Therefore, many pretreatment methods were investigated to overcome the recalcitrance of

11 lignocellulosic materials (Hendriks \& Zeeman, 2009).

12 For instance, the dilute acid method is effective for herbaceous biomass and some hardwoods,

13 sulfite methods are needed for adequate yield for softwood biomass, and simple size reduction

14 increases pretreatment efficiency in both types of processes (Ballesteros et al., 2000; Liu et al.,

15 2013; Shuai et al., 2010; Silva et al., 2012; Zhou et al., 2013). However, single chemical or

16 mechanical treatment method may result in extreme pretreatment conditions or unsatisfactory

17 total sugar yield (Ballesteros et al., 2000; Liu et al., 2013; Mais et al., 2002). As a result, some

18 researchers have deployed combined treatments to achieve good treatment performance with low

19 severity conditions (Jin \& Chen, 2006; Li et al., 2016).

20 The combinations of mechanical and chemical treatment were investigated to improve the total

21 sugar yield (Inoue et al., 2008; Miura et al., 2012; Peng et al., 2013; Yuan et al., 2015; Zakaria et

22 al., 2014). Fine milling such as ball milling was widely adopted in combined treatments. Ball

23 milling altered ultrastructural properties of materials, i.e. crystallinity and particle size 
1 (Schwanninger et al., 2004; Yang et al., 2014). However, the influence of ultrastructural changes

2 in the kinetics of monomeric sugars production and degradation in chemical treatment have not

3 been revealed. Also, the relationship between ultrastructure characteristics of raw materials and

4 total sugar yield have not been correlated quantitively. Also, researchers may have a concern

5 about the energy cost in the fine milling process. However, some of our ongoing works show that

6 proper utilizing multi-step milling process and appropriate mill types can save a large amount of

7 energy (Liu et al., 2016b).

8 In addition, monomeric sugars were core products in the bioconversion studies. Other products

9 yielding in the chemical treatment process, such as acetic acid, furfural, hydroxymethylfurfural

10 (HMF) and lignosulfonates (LS), may either bring profits in a bio-refinery or inhibits enzymatic

11 hydrolysis yields (Jönsson et al., 2013). Lignosulfonates can be a co-products in biorefinery

12 instead of lignin based polymer, which has been widely investigated in current researches ( $\mathrm{Li} \&$

13 McDonald, 2014; Li et al., 2015a; Li et al., 2014; Li et al., 2015b). Therefore, investigating the

14 influence of ultrastructural changes on the yield of these products is meaningful.

15 Considering these gaps in current research we established this study to investigate the influence

16 of ultrastructural changes in raw materials on the kinetics of monomeric sugars production and

17 degradation in the chemical treatment process. Meantime, the response of co-products yield to

18 ultrastructural changes was investigated. Also, the relationship between ultrastructural changes

19 and total sugar yields in chemical treatment and enzymatic hydrolysis were correlated.

\section{Materials and Methods}

\section{Materials preparation and characterization}

22 Douglas-fir (Pseudotsuga menziesii) micronized wood powder was prepared by an impact mill

23 (Zhenzhou Tianyuan Environmental Protection Machinery Co. Ltd, China) with 30 min milling 
1 of $2 \mathrm{~mm}$ wood chips. The particle size of this wood powders was characterized by Malvern

2 particle size analyzer (Mastersizer 3000 laser diffraction). The median particle size (D50) of this

3 sample is $32 \mu \mathrm{m}$ with a standard deviation $1.2 \mu \mathrm{m}$. A planetary ball mill (Across International,

4 PQ-N04, two $100 \mathrm{~mL}$ steel jars, 100 steel balls with a diameter of $6 \mathrm{~mm}$ and 16 steel balls with a

5 diameter of $10 \mathrm{~mm}$ in each jar) was employed to mill the wood powders at two conditions 30 and

$660 \mathrm{~min}$. Therefore, three types of raw materials were employed in this study, unball-milled

7 materials (BM 0), ball milled $30 \mathrm{~min}$ (BM 30), and ball milled 60 min (BM 60).

8 Images of wood particles were obtained through Scanning electron microscopy (SEM) (FEI

9 Quanta 200F, field emission gun, high vacuum, ETD detectors, FEI Company, Hillsboro, Oregon,

10 USA) after sputter coating with gold.

11 Acid bisulfite pretreatment

12 Acid bisulfite method was used to prepare the materials for enzymatic hydrolysis. $145^{\circ} \mathrm{C}$ was

13 selected as the treatment temperature and treatment duration time was 20 to $80 \mathrm{~min}$ for ball

14 milled materials, while 20 to 180 min for materials without ball milling(Liu et al., 2016a; Liu et

15 al., 2016c). Two replicates were carried out for each pretreatment. The cooking liquor has a

$16 \mathrm{Ca}\left(\mathrm{HSO}_{3}\right)_{2}$ concentration of $34.41 \mathrm{~g} / \mathrm{kg}$. The solid to liquid ratio is $1: 4$. Therefore, $25 \mathrm{ml}$ cooking

17 liquor and $15 \mathrm{ml}$ water were mixed to achieve $6.6 \%$ sulfur dioxide loading. $100 \mathrm{ml}$ Parr reactor

18 (No. 4845) was employed for treatments. It took about 30 minutes to reach $145{ }^{\circ} \mathrm{C}$ and 15

19 minutes to cool it to room temperature. After treatment, the slurry was separated through vacuum

20 filtration. The spent liquor was collected for sugars, LS, acetic acid and sugar degradation

21 products (furfural and HMF)) analysis. Pretreated solids were washed and stored in $4^{\circ} \mathrm{C}$

22 refrigerator before use.

23 Spent liquor analysis 
1 The spent liquors were analyzed for sugar, furfural, HMF, acetic acid, and LS content. Two

2 replicates were tested for each sample. The monomeric and oligomer sugars in spent liquor were

3 measured according to NREL standard (Sluiter et al., 2006). The monomeric sugar concentration

4 was measured by anion exchange chromatography (Dionex ICS-3000, CarboPac PA20 Guard

5 column: $4 \times 50 \mathrm{~mm}$ and IonPac AS11-HC analytical column: $4 \times 250 \mathrm{~mm}$, ED40

6 electrochemical detector, AS40 auto sampler, degassed E-pure water, 50mM and 200mM NaOH

7 solution as eluent with a flow rate $0.5 \mathrm{ml} / \mathrm{min}$ ). Oligomer sugar in spent liquor need to be

8 hydrolyzed into monomeric sugar firstly and then measured by Dionex ICS-3000.

9 The concentration of degradation products was measured by high-performance liquid

10 chromatography (HPLC) using a Waters HPLC (Waters, Milford, MA) equipped with

11 differential refractive index detector (ERC-5710, ERMA), a Rezex ROA organic acid column

$12(7.8 \mathrm{~mm} \times 30 \mathrm{~cm}$, Phenomenex, Torrance, $\mathrm{CA})$, on elution with $0.005 \mathrm{~N}$ aqueous $\mathrm{H}_{2} \mathrm{SO}_{4}$ with a

13 flow rate of $0.5 \mathrm{~mL} / \mathrm{min}$ at $65^{\circ} \mathrm{C}$.

14 The concentration of LS was measured with UV-Visible spectrophotometer with a scan range

15 from 200 to $400 \mathrm{~nm}$ at a $0.5 \mathrm{~nm}$ interval ( Perkin Elmer Lambda 35, PerkinElmer, Inc. Waltham,

16 MA ) and calculated according to the absorbance at the wavelength of $232.5 \mathrm{~nm}$ with an

17 extinction coefficient of 24.5 (Llano et al., 2012; Marqués et al., 2009).

18 X-ray diffractometer (XRD) analysis

19 XRD analysis of the BM wood powders and control samples were conducted with an X-ray 20 diffractometer (Miniflex 600, Rigaku, Japan) operated at 40V and 15mA with Ni-filtered $\mathrm{Cu}-\mathrm{Ka}$

21 radiation. Two replicates were tested for each sample. The samples were scanned with the $2 \theta$

22 range of $10-40^{\circ}$ at a scan speed of $2^{\circ} \min ^{-1}$ and step size 0.005 . The crystallinity index (CrI) of 23 each sample was analyzed using the following equation. 
2 Where $\mathrm{I}_{002}$ is the intensity of the 002 peak at $2 \theta=22.4^{\circ}$, and $\mathrm{I}_{\mathrm{am}}$ is the intensity of the background

3 scatter at $2 \theta=18.5^{\circ}$, which is the characteristic peak of cellulose-I.

\section{$4 \quad$ Fourier transform infrared (FTIR) analysis}

5 The pretreated samples for Fourier transform infrared analysis were prepared by drying in

6 convection Oven at $45{ }^{\circ} \mathrm{C}$ for $24 \mathrm{~h}$. Two replicates were tested for each sample. These tests were

7 carried out with a Thermo Nicolet Avatar 370 spectrometer operating in the attenuated total

8 reflection (ATR) mode (Smart performance, ZnSe crystal performance, ZnSe crystal). The

$9 \quad$ spectra were used to analyze chemical bands difference among various treatment conditions (Liu

10 et al., 2013; Sun et al., 2005).

11 Enzymatic hydrolysis

12 Cellic $^{\circledR}$ CTec2 and HTec2 was complimentarily provided by Novozymes North America

13 (Franklinton, NC). The pretreated solids from acid bisulfite cooking were hydrolyzed for 72

14 hours with a $4 \%(\mathrm{w} / \mathrm{w})$ CTec2 and $0.4 \%(\mathrm{w} / \mathrm{w})$ HTec2 (based on oven dry wood basis) enzyme

15 product loading. The solid loading was $2 \%(\mathrm{w} / \mathrm{v})$ of a total $50 \mathrm{ml}$ volume. $0.5 \mathrm{ml} 2 \%(\mathrm{w} / \mathrm{w})$

16 sodium azide were used for antibacterial function in hydrolysis slurry. The supernatant was

17 collected after 72 hours' hydrolysis and diluted 500-fold for analysis of monomeric sugars. Two

18 replicates were carried out for the enzymatic hydrolysis of each pretreated sample. Total sugar

19 yield is the overall sugar recovery from both acid bisulfite treatment process and enzymatic

20 hydrolysis.

\section{Modeling theory}

22 Acid bisulfite treatment is a heterogeneous acid hydrolysis process involving a solid-state 23 substrate and a liquid state catalyst. The reaction rate of this process depends on a number of 
1 variables, such as temperature, acid concentration, time and substrate concentration (Lenihan et

2 al., 2011). The main objectives of the current kinetic modeling are 1) understanding this reaction

3 kinetics of multiple products in the chemical treatment process, 2) establishing an index (reaction

4 rate constants) for multiple products yield evaluation.

5 The Saeman model (Saeman, 1945) was first proposed to investigate sulfuric acid hydrolysis of

6 Douglas-fir wood. This model was established under the assumption that the reactions happened

7 during acid hydrolysis are irreversible pseudo-homogeneous first order reactions. The process

8 can be expressed as follows:

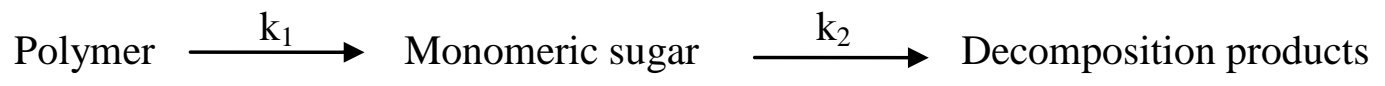

9

10

11

12 Where: $\mathrm{k}_{1}=$ The rate constant of polymer to monomer, $\min ^{-1}$

21 Where: $\mathrm{C}_{\mathrm{m}}=$ Monomeric sugar concentration, $\mathrm{g} \mathrm{L}^{-1}$

$$
\frac{d P}{d t}=-k_{1} P
$$

$$
\frac{d M}{d t}=k_{1} P-k_{2} C
$$

$$
\mathrm{P}, \mathrm{C}=\text { Concentration of polymer and monomer sugar, } \mathrm{g} \mathrm{L}^{-1}
$$
1945; Zhuang et al., 2009):

(9)

$$
\mathrm{P}_{0}=\text { Initial Polymer concentration, } \mathrm{g} \mathrm{L}^{-1}
$$

$$
\mathrm{k}_{2}=\text { The rate constant of monomer to decomposition products, } \min ^{-1}
$$

Polymeric sugars are glucan, xylan, mannan, galactan, and arabinan. From this reaction mode and solving differential equations (1) and (2), the monomeric sugar concentration (C) as a function of time (t) can be represented by (Malester et al., 1992; Rahman et al., 2006; Saeman,

$$
\begin{array}{r}
C_{m}=\frac{P_{0} k_{1}}{\left(k_{2}-k_{1}\right)} \times\left(e^{-k_{1} t}-e^{-k_{2} t}\right) \\
Y=\frac{C_{m}}{P_{0}}=\frac{k_{1}}{k_{2}-k_{1}} \times\left(e^{-k_{1} t}-e^{-k_{2} t}\right)
\end{array}
$$




$$
\mathrm{Y}=\text { Monomeric sugar yield in percent, } \%
$$

2 After obtaining $\mathrm{k}_{1}$ and $\mathrm{k}_{2}$, the time at which the maximum sugar yield was reached can be

3 calculated as:

$$
\mathrm{t}=\frac{\ln k_{2}-\ln k_{1}}{k_{2}-k_{1}}
$$

5 In order to investigate the effects on sugar degradation products yield, a kinetic modeling was

6 also employed.

$$
C_{i}=C_{i 0}\left(1-e^{-k_{i} t}\right)
$$

8 Where: $\mathrm{C}_{\mathrm{i}}=$ Acetic acid or HMF \& Furfural concentration, $\mathrm{g} \mathrm{L}^{-1}$

$$
\mathrm{C}_{\mathrm{i} 0}=\text { Regression parameters, potential concentrations, } \mathrm{g} \mathrm{L}^{-1}
$$

$$
\mathrm{k}_{\mathrm{i}}=\text { The rate constants of reactions, } \min ^{-1}
$$

\section{Results and discussion}

\section{Particle size and crystallinity characterization}

14 Original micronized wood powder and BM wood powders were characterized by particle size

15 distribution and cellulose crystallinity. Figure 1 shows the median particle size decreased from

1632 to $17 \mu \mathrm{m}$ and $18 \mu \mathrm{m}$ after 30 and $60 \mathrm{~min}$ ball milling, respectively. The peak of size

17 distribution curve shifted to a small size after ball milling. However, the BM 60 wood powders

18 had a larger size compared to the particle size of BM 30 wood powders, which may be attributed

19 to wood particles agglomeration (Gharpuray et al., 1983; Yu \& Wu, 2011; Zhang et al., 2007). 
1 XRD analysis demonstrates that the cellulose crystallinity of wood powders decreased along

2 with an increase of the milling time. The peak at $18.5^{\circ}$ disappeared for ball milled materials,

3 which indicated the transition of crystalline structure to amorphous structure. The $\mathrm{CrI}$ decreased

4 from 0.41 to 0.20 and 0.10 after 30 and 60 min ball milling, respectively.

5 SEM analysis showed that the cell wall structure of wood powder was destroyed after ball

6 milling. The wood powders became smaller after $30 \mathrm{~min}$ ball milling. However, the particles

7 obtained from $60 \mathrm{~min}$ ball milling become larger than the particles from $30 \mathrm{~min}$. This finding is

8 consistent with the above results of particle size analysis.

\section{Monomeric sugars production and degradation}

10 Per this modeling theory, we measured monomeric sugars' concentration in spent liquor. Initial

11 polymer concentration can be obtained per the compositional analysis of raw materials (as shown

12 in Table 1). Then, $\mathrm{k}_{1}$ and $\mathrm{k}_{2}$ can be obtained through least squares fitting using Eq.3 and $\mathrm{t}$ can be

13 calculated by Eq.5. These parameters were summarized in Table 1.

14 Ball milling process accelerated monomeric sugars production process since the parameter $\mathrm{k}_{1}$ for

15 various sugars increased with $30 \mathrm{~min}$ BM wood powders. Further ball milling did not increase $\mathrm{k}_{1}$

16 significantly. As to $\mathrm{k}_{2}$, ball milling did not show influence on it, which indicates degradation

17 products formation was not influenced by ultrastructural changes. Also, this result was verified

18 by measuring sugar degradation products in spent liquor as shown in Table 2.

19 The treatment time required for achieving maximum sugar in the spent liquor reduced to $45 \mathrm{~min}$

20 for xylan/mannan after 30 min ball milling. Especially, the time required for glucan hydrolysis

21 dropped more than one hour. Also, it can be found that arabinan has quickest reaction rate

22 followed by galactan and xylan/mannan. Glucan is the hardest one to be hydrolyzed in this

23 process, which been significantly improved due to crystalline structure change in cellulose. 
1 Table 2 shows the concentration of sugar degradation products, acetic acid, and LS in the spent

2 liquor. The concentration of these products increased with an increase of treatment time. The

3 increase of ball milling time increased the yield of LS and acetic acid without laying effects on

4 the yields of HMF and furfural. These results are quite approving in pursuit of co-products

5 production boost and high enzymatic hydrolysis yield. In order to quantify the influence of

6 ultrastructural changes (induced by ball milling) on these co-products yield, kinetic modeling of

7 acetic acid and sugar degradation products was carried out according to Eq. 6 (Aguilar et al.,

8 2002). The rate constants were summarized in Table 5.

\section{$9 \quad$ Total sugar yields}

10 After obtaining monomeric sugars and other chemicals from the chemical treatment process,

11 pretreated solids were utilized for cellulosic sugar production with enzymes. Most carbohydrates

12 can be hydrolyzed into monomeric sugars depending on chemical treatment efficiency. The

13 residues from enzymatic hydrolysis are rich in lignin ( $95.1 \%$ lignin and 4.9\% extractives for BM

1460 residues under pretreatment condition: $145^{\circ} \mathrm{C}$ and $40 \mathrm{~min}$ ) and can be further used for other

15 applications such as active carbon production or lignin based polymers (Suhas et al., 2007).

16 Therefore, high carbohydrate hydrolysis yields will result in pure lignin residues, which will be

17 beneficial for utilizing them.

18 Table 3 shows total sugar yield from both chemical treatment and enzymatic hydrolysis under

19 various ball milling and cooking time conditions. Total sugar yield all firstly increased and then

20 decreased along with an increase of cooking time. Maximum total sugar yields: $65 \%, 81 \%$, and

$2192 \%$ were achieved at 120, 40 and 40 min cooking for 0, 30 and 60 min BM wood powders,

22 respectively. 30 min ball milling decreased cooking time and increased total sugar yield.

23 However, further ball milling did not have effects on decreasing chemical treatment time but still 
1 increased total sugar yield by $11 \%$ compared to $30 \mathrm{~min}$ ball milling.

\section{FTIR analysis}

3 Above analysis showed that excessive cooking can lower total sugar yield. It is crucial to explore

4 the underlying mechanism for this phenomenon to optimize pretreatment condition. FTIR was

5 employed to characterize pretreated solids. The bands of chemical groups in BM 30 and BM 60

6 under various chemical treatment conditions were investigated. Band $1731 \mathrm{~cm}^{-1}$ represents $\mathrm{C}=\mathrm{O}$

7 stretch in hemicellulose and lignin. It disappeared after chemical treatment due to hemicellulose

8 and lignin removal. Band 1598/1602 and $1511 \mathrm{~cm}^{-1}$ are the characteristic bands of lignin (Li \&

9 McDonald, 2014). Band $1511 \mathrm{~cm}^{-1}$ can be used for bands intensity normalization (Dizhbite et al.,

10 2011). The bands analyzed in this study were assigned in accordance with (Li et al., 2015b;

11 Marques et al., 2006; Rana et al., 2010; Sun et al., 2002; You et al., 2015): $1646 \mathrm{~cm}^{-1}$ for

12 absorbed water, 1367 and $897 \mathrm{~cm}^{-1}$ for $\mathrm{C}-\mathrm{H}$ deformation in cellulose and hemicellulose, 1315

$13 \mathrm{~cm}^{-1}$ for $\mathrm{C}-\mathrm{H}$ vibration in cellulose, $1267 \mathrm{~cm}^{-1}$ for guaiacyl unit of lignin, $1158 \mathrm{~cm}^{-1}$ for C-O-C

14 vibration in cellulose and hemicellulose, $1104 \mathrm{~cm}^{-1}$ for aromatic skeletal vibration or C-O stretch

15 in lignin or carbohydrates, 1056 and $1030 \mathrm{~cm}^{-1}$ for C-O vibration in cellulose and hemicellulose.

16 The intensities of four bands were normalized and compared among various chemical treatment

17 time to determine chemical groups changes of pretreated solids. As shown in Table 4, the

18 intensity of band $1731 \mathrm{~cm}^{-1}$ decreased after chemical treatment and then increased along with an

19 increase of treatment time. Since this band was $\mathrm{C}=\mathrm{O}$ stretch in hemicellulose or lignin, it

20 decreased due to hemicellulose removal and then increased due to $\mathrm{C}=\mathrm{O}$ stretch from lignin, since

21 lignin content comparatively increased after removing hemicellulose. According to band 1267

$22 \mathrm{~cm}^{-1}$, G-unit lignin decreased along with an increase of treatment time and maintained at the

23 same level after 40 min cooking. The intensity of band $1158 \mathrm{~cm}^{-1}$ indicated cellulose content in 
1 pretreated material firstly increased because of hemicellulose removal and then decreased due to

2 acid hydrolysis of glucan. In general, carbohydrates in raw materials continued to decrease along

3 with an increase of treatment time as proved by the intensity change of band $1030 \mathrm{~cm}^{-1}$. 
1 According to above analysis, it can be concluded that 40 min chemical treatment achieved stable

2 lignin removal and high hemicellulose removal with a small amount of cellulose hydrolysis.

3 With an increase in acid bisulfite pretreatment time, a large amount of cellulose tended to be

4 hydrolyzed with the concomitant of more sugar degradation products, which is harmful to

5 downstream enzymatic hydrolysis. In addition, many studies showed that lignin condensation or

6 pseudo-lignin occurred in hydrothermal treatments (Kumar et al., 2013; Sannigrahi et al., 2011;

7 Sannigrahi et al., 2008), which negatively influenced on total sugar yields. Since LS yields

8 maintain the same amount at 60 and 80 min cooking as shown in Table 2, lignin segments may

9 reconstruct with carbohydrate and formed pseudo lignin, which also inhibited enzymatic

10 hydrolysis of carbohydrates.

\section{Comprehensive analysis}

12 As shown in Table 5, rate constants $\mathrm{k}_{1}$ of xylan/mannan and acetic acid, as well as total sugar

13 yield all increased along with a decrease of crystallinity. Good linear fitting was obtained

14 between these parameters as shown in Figure 2, which indicated that the decrease of crystallinity

15 accelerates xylan/mannan hydrolysis and acetic acid production process, as well as increases

16 total sugar yields. Optimal treatment time and rate constants of glucan showed a plateau between

$17 \quad 30$ and 60 min ball milling, whereas median particle size tended to decrease after 30 min ball

18 milling. Wood powder agglomeration may be responsible for this plateau. Also, the rate

19 constants of HMF and furfural maintained same level indicating ultrastructural changes did not

20 influence on sugar degradation process.

21 Mechanical treatment (ball milling) altered the crystalline structure of materials thus in

22 alleviating chemical treatment severity (decreasing chemical pretreatment duration time) at

23 achieving higher total sugar yield. Also, the yield of sugar degradation products did not increase 
1 when the ultrastructural properties of raw materials changed, which can benefit downstream

2 enzymatic hydrolysis process. In addition, the increasing of LS and acetic acid yield can bring

3 extra profitability for cellulosic sugar production process.

\section{Conclusions}

5 Monomeric sugar production process in acid bisulfite treatment was accelerated with a decrease

6 of crystallinity, however, no difference was found for glucan hydrolysis between 30 and 60 min

7 ball milled materials. The yields of HMF and furfural were not affected by ultrastructural

8 changes, whereas the yields of acetic acid and LS increased as a decrease of crystallinity. In all,

960 min ball milling substantially improved total sugar yield from $65 \%$ to $92 \%$ and significantly

10 decreased chemical treatment time from $120 \mathrm{~min}$ to $40 \mathrm{~min}$. When viewed from the total

11 mechanical-chemical pretreatment time, the $27 \%$ increase in sugar yield was achieved with 20

12 min decrease in time.

13 Acknowledgements

14 The authors are grateful to the financial support from the Northwest Advanced Renewables 15 Alliance (NARA), supported by the Agriculture and Food Research Initiative Competitive Grant 16 no. 2011-68005-30416 from the USDA National Institute of Food and Agriculture, and the

17 China Scholarship Council (CSC) funding for Yalan Liu's living expenses. Thanks to Dr.

18 Johnway Gao from Weyerhaeuser Co. for providing calcium bisulfite cooking liquor and Dr.

19 Armando McDonald for providing HPLC and FTIR in his lab. 


\section{References}

2 1. Aguilar, R., Ramırez, J.A., Garrote, G., Vazquez, M. 2002. Kinetic study of the acid hydrolysis of sugar cane bagasse. J Food Eng, 55, 309-318.

2. Ballesteros, I., Oliva, J.M., Navarro, A.A., Gonzalez, A., Carrasco, J., Ballesteros, M. 2000. Effect of chip size on steam explosion pretreatment of softwood. Appl Biochem Biotech,

3. Dizhbite, T., Telysheva, G., Dobele, G., Arshanitsa, A., Bikovens, O., Andersone, A., Kampars, V. 2011. Py-GC/MS for characterization of non-hydrolyzed residues from

4. Gharpuray, M.M., Lee, Y.H., Fan, L.T. 1983. Structural Modification of Lignocellulosics by

Pretreatments to Enhance Enzymatic-Hydrolysis. Biotechnol Bioeng, 25, 157-172.

5. Hendriks, A.T.W.M., Zeeman, G. 2009. Pretreatments to enhance the digestibility of lignocellulosic biomass. Bioresource Technol, 100, 10-18.

6. Himmel, M.E., Ding, S.Y., Johnson, D.K., Adney, W.S., Nimlos, M.R., Brady, J.W., Foust, T.D. 2007. Biomass recalcitrance: Engineering plants and enzymes for biofuels production. Science, 315, 804-807.

7. Inoue, H., Yano, S., Endo, T., Sakaki, T., Sawayama, S. 2008. Combining hot-compressed water and ball milling pretreatments to improve the efficiency of the enzymatic hydrolysis of eucalyptus. Biotechnol Biofuels, 1, 2.

8. Jeoh, T., Ishizawa, C.I., Davis, M.F., Himmel, M.E., Adney, W.S., Johnson, D.K. 2007. Cellulase digestibility of pretreated biomass is limited by cellulose accessibility. Biotechnol Bioeng, 98, 112-122.

9. Jin, S., Chen, H. 2006. Superfine grinding of steam-exploded rice straw and its enzymatic hydrolysis. Biochem Eng J, 30, 225-230. 
10. Jönsson, L.J., Alriksson, B., Nilvebrant, N.-O. 2013. Bioconversion of lignocellulose: inhibitors and detoxification. Biotechnol Biofuels, 6, 16.

11. Kumar, R., Hu, F., Sannigrahi, P., Jung, S., Ragauskas, A.J., Wyman, C.E. 2013. Carbohydrate derived-pseudo-lignin can retard cellulose biological conversion. Biotechnol Bioeng, 110, 737-753.

12. Kumar, R., Wyman, C.E. 2014. Strong cellulase inhibition by Mannan polysaccharides in cellulose conversion to sugars. Biotechnol Bioeng, 111, 1341-1353.

13. Lenihan, P., Orozco, A., O’Neill, E., Ahmad, M.N.M., Rooney, D.W., Mangwandi, C., Walker, G.M. 2011. Kinetic Modelling of Dilute Acid Hydrolysis of Lignocellulosic Biomass,. in: Biofuel Production-Recent Developments and Prospects, (Ed.) D.M.A.D.S. Bernardes.

14. Li, H., McDonald, A.G. 2014. Fractionation and characterization of industrial lignins. Ind Crop Prod, 62, 67-76.

15. Li, H., Sivasankarapillai, G., McDonald, A.G. 2015a. Highly biobased thermally-stimulated shape memory copolymeric elastomers derived from lignin and glycerol-adipic acid based hyperbranched prepolymer. Ind Crop Prod, 67, 143-154.

16. Li, H., Sivasankarapillai, G., McDonald, A.G. 2014. Lignin Valorization by Forming Thermally Stimulated Shape Memory Copolymeric Elastomers-Partially Crystalline Hyperbranched Polymer as Crosslinks. J Appl Polym Sci, 131, 12050-12060.

17. Li, H., Sivasankarapillai, G., McDonald, A.G. 2015b. Lignin Valorization by Forming Toughened Thermally Stimulated Shape Memory Copolymeric Elastomers: Evaluation of Different Fractionated Industrial Lignins. J Appl Polym Sci, 132, 1505-1517. 
18. Li, H.Y., Chen, X., Wang, C.Z., Sun, S.N., Sun, R.C. 2016. Evaluation of the two-step treatment with ionic liquids and alkali for enhancing enzymatic hydrolysis of Eucalyptus: chemical and anatomical changes. Biotechnol Biofuels, 9, 166.

19. Liu, Y., Wang, J., Wolcott, M. 2016a. Modeling the production of sugar and byproducts from acid bisulfite pretreatment and enzymatic hydrolysis of Douglas-fir. Bioresource Technol, DOI: 10.1016/j.biortech.2016.10.071.

20. Liu, Y., Wang, J., Wolcott, M.P. 2016b. Assessing the specific energy consumption and physical properties of comminuted Douglas-fir chips for bioconversion. Ind Crop Prod, 94, 394-400.

21. Liu, Y., Wang, J., Wolcott, M.P. 2016c. Multistep Process to Produce Fermentable Sugars and Lignosulfonates from Softwood Enzymolysis Residues. ACS Sustainable Chem. Eng., DOI: 10.1021/acssuschemeng.6b02328.

22. Liu, Z.-H., Qin, L., Pang, F., Jin, M.-J., Li, B.-Z., Kang, Y., Dale, B.E., Yuan, Y.-J. 2013. Effects of biomass particle size on steam explosion pretreatment performance for improving the enzyme digestibility of corn stover. Ind Crop Prod, 44, 176-184.

23. Llano, T., Rueda, C., Quijorna, N., Blanco, A., Coz, A. 2012. Study of the delignification of hardwood chips in a pulping process for sugar production. J Biotechnol, 162, 422-429.

24. Mais, U., Esteghlalian, A.R., Saddler, J.N., Mansfield, S.D. 2002. Enhancing the Enzymatic Hydrolysis of Cellulosic Materials Using Simultaneous Ball Milling. Appl Biochem Biotech, 98-100, 815-832.

25. Malester, I.A., Green, M., Shelef, G. 1992. Kinetics of Dilute Acid Hydrolysis of Cellulose Originating from Municipal Solid Wastes. Ind Eng Chem Res, 31, 1998-2003. 
26. Marqués, A.P., Evtuguin, D.V., Magina, S., Amado, F.M.L., Prates, A. 2009. Chemical composition of spent liquors from acidic magnesium-based sulphite pulping of Eucalyptus globulus. J Wood Chem Technol, 29, 322-336.

27. Marques, A.V., Pereira, H., Rodrigues, J., Meier, D., Faix, O. 2006. Isolation and comparative characterization of a Bjorkman lignin from the saponified cork of Douglasfir bark. J Anal Appl Pyrol, 77, 169-176.

28. Miura, T., Lee, S.-H., Inoue, S., Endo, T. 2012. Combined pretreatment using ozonolysis and wet-disk milling to improve enzymatic saccharification of Japanese cedar. Bioresource Technol, 126, 182-186.

29. Peng, H., Li, H., Luo, H., Xu, J. 2013. A novel combined pretreatment of ball milling and microwave irradiation for enhancing enzymatic hydrolysis of microcrystalline cellulose. Bioresource Technol, 130, 81-87.

30. Rahman, S.H.A., Choudhury, J.P., Ahmad, A.L. 2006. Production of xylose from oil palm empty fruit bunch fiber using sulfuric acid. Biochem Eng J, 30, 97-103.

31. Rana, R., Langenfeld-Heyser, R., Finkeldey, R., Polle, A. 2010. FTIR spectroscopy, chemical and histochemical characterisation of wood and lignin of five tropical timber wood species of the family of Dipterocarpaceae. Wood Sci Technol, 44, 225-242.

32. Rowell, R.M., Pettersen, R., Han, J.S., Rowell, J.S., Tshabalala, M.A. 2005. Cell wall chemistry. in: Handbook of wood chemistry and wood composites, pp. 35-74.

33. Saeman, J.F. 1945. Kinetics of Wood Saccharification - Hydrolysis of Cellulose and Decomposition of Sugars in Dilute Acid at High Temperature. Ind Eng Chem, 37, 43-52.

34. Sannigrahi, P., Kim, D.H., Jung, S., Ragauskas, A. 2011. Pseudo-lignin and pretreatment chemistry. Energ Environ Sci, 4, 1306-1310. 
35. Sannigrahi, P., Ragauskas, A.J., Miller, S.J. 2008. Effects of two-stage dilute acid pretreatment on the structure and composition of lignin and cellulose in loblolly pine. Bioenergy Res, 1, 205-214.

36. Schwanninger, M., Rodrigues, J.C., Pereira, H., Hinterstoisser, B. 2004. Effects of short-time vibratory ball milling on the shape of FT-IR spectra of wood and cellulose. Vib Spectrosc, $36,23-40$.

37. Shuai, L., Yang, Q., Zhu, J.Y., Lu, F.C., Weimer, P.J., Ralph, J., Pan, X.J. 2010. Comparative study of SPORL and dilute-acid pretreatments of spruce for cellulosic ethanol production. Bioresource Technol, 101, 3106-3114.

38. Silva, G.G.D., Couturier, M., Berrin, J.-G., Buléon, A., Rouau, X. 2012. Effects of grinding processes on enzymatic degradation of wheat straw. Bioresource Technol, 103, 192-200.

39. Sluiter, A., Hames, B., Ruiz, R., Scarlata, C., Sluiter, J., Templeton, D. 2006. Determination of Sugars byproducts and degradation products in liquid fraction process samples. in: Laboratory Analytical Procedure from the National Renewable Energy Laboratory Biomass Analysis Technology (NREL BAT) Team.

40. Suhas, Carrott, P.J.M., Ribeiro Carrott, M.M.L. 2007. Lignin - from natural adsorbent to activated carbon: A review. Bioresource Technol, 98, 2301-2312.

41. Sun, R.C., Sun, X.F., Fowler, P., Tomkinson, J. 2002. Structural and physico-chemical characterization of lignins solubilized during alkaline peroxide treatment of barley straw. Eur Polym J, 38, 1399-1407.

42. Sun, X.F., Xu, F., Sun, R.C., Fowler, P., Baird, M.S. 2005. Characteristics of degraded cellulose obtained from steam-exploded wheat straw. Carbohyd Res, 340, 97-106. 
43. Yang, Y., Ji, G., Xiao, W., Han, L. 2014. Changes to the physicochemical characteristics of wheat straw by mechanical ultrafine grinding. Cellulose, 21, 3257-3268.

44. You, T.T., Zhang, L.M., Zhou, S.K., Xu, F. 2015. Structural elucidation of lignincarbohydrate complex (LCC) preparations and lignin from Arundo donax Linn. Ind Crop Prod, 71, 65-74.

45. Yu, Y., Wu, H.W. 2011. Effect of Ball Milling on the Hydrolysis of Microcrystalline Cellulose in Hot-Compressed Water. Aiche J, 57, 793-800.

46. Yuan, Z., Long, J., Wang, T., Shu, R., Zhang, Q., Ma, L. 2015. Process intensification effect of ball milling on the hydrothermal pretreatment for corn straw enzymolysis. Energy Convers Manage, 101, 481-488.

47. Zakaria, M.R., Hirata, S., Hassan, M.A. 2014. Combined pretreatment using alkaline hydrothermal and ball milling to enhance enzymatic hydrolysis of oil palm mesocarp fiber. Bioresource Technol, 169, 236-243.

48. Zhang, W., Liang, M., Lu, C. 2007. Morphological and structural development of hardwood cellulose during mechanochemical pretreatment in solid state through pan-milling. Cellulose, 14, 447-456.

49. Zhou, S., Osman, N.B., Li, H., McDonald, A.G., Mourant, D., Li, C.Z., Garcia-Perez, M. 2013. Effect of sulfuric acid addition on the yield and composition of lignin derived oligomers obtained by the auger and fast pyrolysis of Douglas-fir wood. Fuel, 103, 512523.

50. Zhuang, X., Yuan, Z., Ma, L., Wu, C., Xu, M., Xu, J., Zhu, S., Qi, W. 2009. Kinetic study of hydrolysis of xylan and agricultural wastes with hot liquid water. Biotechnol Adv, 27, $578-582$. 


\section{Table Captions}

Table 1. Rate constants of monomeric sugar production and degradation obtained by Saeman model fitting.

Table 2 The concentrations of LS, acetic acid, HMF, and furfural in the spent liquors.

Table 3 Total sugar yields from spent liquor and enzymatic hydrolysis under various conditions.

Table 4 FTIR bands intensity normalization by $1511 \mathrm{~cm}^{-1}$.

Table 5 Comprehensive analysis between ultrastructural properties and total sugar yields, rate constants of multiple products.

\section{Figure Captions}

Figure 1. Particle size distribution of 0,30 and 60 min ball milled materials

Figure 2. Linear fitting between CrI and rate constants, total sugar yield. 
Table 1

\begin{tabular}{|c|c|c|c|c|c|c|c|c|c|c|c|c|c|}
\hline \multirow[b]{2}{*}{ Sugar type } & \multirow{2}{*}{$\begin{array}{c}\text { Compo } \\
\text { sition } \\
(\%)\end{array}$} & \multicolumn{3}{|c|}{ BM 0} & \multirow[b]{2}{*}{$\mathrm{R}^{2}$} & \multicolumn{4}{|c|}{ BM 30} & \multicolumn{4}{|c|}{ BM 60} \\
\hline & & $\mathrm{k}_{1}$ & $\mathrm{k}_{2}$ & $\begin{array}{l}\text { Time } \\
(\min )\end{array}$ & & $\mathrm{k}_{1}$ & $\mathrm{k}_{2}$ & $\begin{array}{l}\text { Time } \\
\text { (min) }\end{array}$ & $\mathrm{R}^{2}$ & $\mathrm{k}_{1}$ & $\mathrm{k}_{2}$ & $\begin{array}{l}\text { Time } \\
(\min )\end{array}$ & $\mathrm{R}^{2}$ \\
\hline Arabinan & 1.16 & 0.1680 & 0.0121 & 17 & 0.97 & 0.4371 & 0.0098 & 9 & 0.90 & 0.4609 & 0.0132 & 8 & 0.93 \\
\hline Galactan & 2.97 & 0.0272 & 0.0062 & 70 & 0.95 & 0.0345 & 0.0100 & 51 & 0.99 & 0.0445 & 0.0142 & 38 & 0.99 \\
\hline Glucan & 38.12 & 0.0015 & 0.0087 & 247 & 0.96 & 0.0045 & 0.0075 & 170 & 0.97 & 0.0045 & 0.0084 & 160 & 0.99 \\
\hline Xylan/mannan & 13.00 & 0.0208 & 0.0079 & 75 & 0.99 & 0.0362 & 0.0127 & 45 & 0.99 & 0.0405 & 0.0117 & 43 & 0.99 \\
\hline
\end{tabular}


Table 2

\begin{tabular}{cccccccccc}
\hline $\begin{array}{c}\text { Ball } \\
\text { mill } \\
\text { time } \\
(\mathrm{min})\end{array}$ & $\begin{array}{c}\text { Cooking } \\
\text { time } \\
(\mathrm{min})\end{array}$ & \multicolumn{2}{c}{ LS $(\mathrm{g} / \mathrm{L})$} & \multicolumn{2}{c}{ Acetic acid $(\mathrm{g} / \mathrm{L})$} & HMF $(\mathrm{g} / \mathrm{L})$ & \multicolumn{2}{c}{ Furfural $(\mathrm{g} / \mathrm{L})$} \\
& 20 & 27.18 & 2.38 & 0.83 & 0.11 & 0.08 & 0.00 & 0.25 & 0.00 \\
& 40 & 32.29 & 0.26 & 1.21 & 0.02 & 0.21 & 0.00 & 0.43 & 0.08 \\
0 & 60 & 37.00 & 2.11 & 1.33 & 0.12 & 0.38 & 0.03 & 0.92 & 0.29 \\
& 120 & 46.69 & 1.76 & 1.69 & 0.05 & 1.45 & 0.07 & 1.68 & 0.05 \\
& 180 & 49.57 & 1.59 & 2.72 & 0.22 & 2.30 & 0.06 & 2.37 & 0.32 \\
& 20 & 32.5 & 0.17 & 1.02 & 0.12 & 0.09 & 0.00 & 0.22 & 0.00 \\
30 & 40 & 41.4 & 2.18 & 1.59 & 0.02 & 0.19 & 0.00 & 0.50 & 0.05 \\
& 60 & 45.5 & 0.13 & 1.66 & 0.11 & 0.25 & 0.01 & 0.75 & 0.08 \\
& 80 & 45.4 & 0.31 & 2.71 & 0.14 & 0.30 & 0.01 & 1.27 & 0.10 \\
& 20 & 33.2 & 0.10 & 1.50 & 0.07 & 0.09 & 0.00 & 0.26 & 0.00 \\
60 & 40 & 46.8 & 0.27 & 2.17 & 0.09 & 0.22 & 0.00 & 0.57 & 0.02 \\
& 60 & 50.2 & 0.02 & 2.68 & 0.10 & 0.25 & 0.00 & 0.85 & 0.05 \\
& 80 & 51.5 & 0.33 & 3.25 & 0.20 & 0.35 & 0.02 & 1.38 & 0.13 \\
\hline
\end{tabular}


Table 3

\begin{tabular}{cccccccc}
\hline $\begin{array}{c}\text { Ball mill } \\
\text { time (min) }\end{array}$ & $\begin{array}{c}\text { Cooking } \\
\text { time }(\min )\end{array}$ & $\begin{array}{c}\text { Arabinan } \\
(\%)\end{array}$ & $\begin{array}{c}\text { Galactan } \\
(\%)\end{array}$ & $\begin{array}{c}\text { Glucan } \\
(\%)\end{array}$ & $\begin{array}{c}\text { Xylan/Mannan } \\
(\%)\end{array}$ & \multicolumn{2}{c}{ Total (\%) } \\
\hline \multirow{3}{*}{0} & 0 & 0.0 & 0.0 & 14.9 & 8.7 & 12.3 & 0.1 \\
& 60 & 53.7 & 82.4 & 48.2 & 81.5 & 58.0 & 1.5 \\
& 120 & 40.4 & 71.1 & 66.2 & 64.2 & 65.5 & 0.1 \\
& 180 & 19.1 & 41.7 & 58.2 & 33.8 & 50.7 & 0.1 \\
\cline { 2 - 7 } & 0 & 10.3 & 0.0 & 51.4 & 23.2 & 41.2 & 0.6 \\
30 & 20 & 56.3 & 69.1 & 71.8 & 69.3 & 70.7 & 2.4 \\
& 40 & 43.1 & 74.3 & 85.2 & 73.9 & 81.0 & 0.4 \\
& 60 & 34.4 & 63.7 & 76.5 & 64.9 & 72.2 & 0.2 \\
& 80 & 31.5 & 58.1 & 74.4 & 63.1 & 69.9 & 0.2 \\
\hline \multirow{3}{*}{60} & 0 & 12.6 & 0.0 & 64.9 & 26.4 & 51.3 & 0.3 \\
& 20 & 61.8 & 66.1 & 90.0 & 74.8 & 84.6 & 0.6 \\
& 40 & 54.6 & 73.9 & 98.1 & 81.7 & 92.0 & 0.3 \\
& 60 & 49.4 & 70.1 & 88.3 & 70.2 & 82.2 & 3.5 \\
\hline
\end{tabular}


Table 4

\begin{tabular}{|c|c|c|c|c|c|c|}
\hline \multirow{2}{*}{$\begin{array}{l}\text { Wave number } \\
\qquad\left(\mathrm{cm}^{-1}\right)\end{array}$} & \multirow{2}{*}{ Band origin } & \multicolumn{5}{|c|}{ Cooking time (min) } \\
\hline & & 0 & 20 & 40 & 60 & 80 \\
\hline 1731 & $\begin{array}{l}\mathrm{C}=\mathrm{O} \text { stretch in } \\
\text { hemi/lignin }\end{array}$ & 0.70 & 0.19 & 0.29 & 0.32 & 0.33 \\
\hline 1267 & $\begin{array}{l}\text { Guaiacyl unit of } \\
\text { lignin }\end{array}$ & 1.50 & 1.33 & 1.28 & 1.28 & 1.24 \\
\hline 1158 & $\begin{array}{l}\text { C-O-C vibration } \\
\text { Cellulose }\end{array}$ & 1.47 & 1.80 & 1.96 & 1.95 & 1.81 \\
\hline 1030 & $\begin{array}{l}\mathrm{C}-\mathrm{O} \text { vibration in } \\
\text { Carbohydrate }\end{array}$ & 4.21 & 4.06 & 4.01 & 3.89 & 3.67 \\
\hline
\end{tabular}


Table 5

\begin{tabular}{|c|c|c|c|c|c|c|c|c|}
\hline \multirow{2}{*}{$\begin{array}{l}\text { Ball } \\
\text { mill } \\
\text { time } \\
(\mathrm{min})\end{array}$} & \multicolumn{2}{|c|}{$\begin{array}{l}\text { Ultrastructure } \\
\text { properties }\end{array}$} & \multirow{2}{*}{$\begin{array}{l}\text { Optimal } \\
\text { treatment } \\
\text { time } \\
(\mathrm{min})\end{array}$} & \multicolumn{2}{|c|}{$\begin{array}{l}\text { Rate constants } \mathrm{k}_{1} \\
\text { of }\end{array}$} & \multicolumn{2}{|c|}{$\begin{array}{l}\text { Rate constants } \mathrm{k}_{\mathrm{i}} \\
\text { of }\end{array}$} & \multirow{2}{*}{$\begin{array}{l}\text { Total sugar } \\
\text { yield }(\%)\end{array}$} \\
\hline & $\mathrm{CrI}$ & $\begin{array}{c}\text { Median } \\
\text { size } \\
(\mu \mathrm{m})\end{array}$ & & $\begin{array}{l}\text { Xylan/M } \\
\text { annan }\end{array}$ & Glucan & $\begin{array}{l}\text { Acetic } \\
\text { acid }\end{array}$ & $\begin{array}{l}\text { HMF\& } \\
\text { Furfural }\end{array}$ & \\
\hline 0 & 0.41 & 32 & 120 & 0.0208 & 0.0015 & 0.0111 & 0.00036 & 65 \\
\hline 30 & 0.20 & 17 & 40 & 0.0362 & 0.0045 & 0.0130 & 0.00033 & 81 \\
\hline 60 & 0.10 & 18 & 40 & 0.0405 & 0.0045 & 0.0222 & 0.00036 & 92 \\
\hline
\end{tabular}


Figure 1

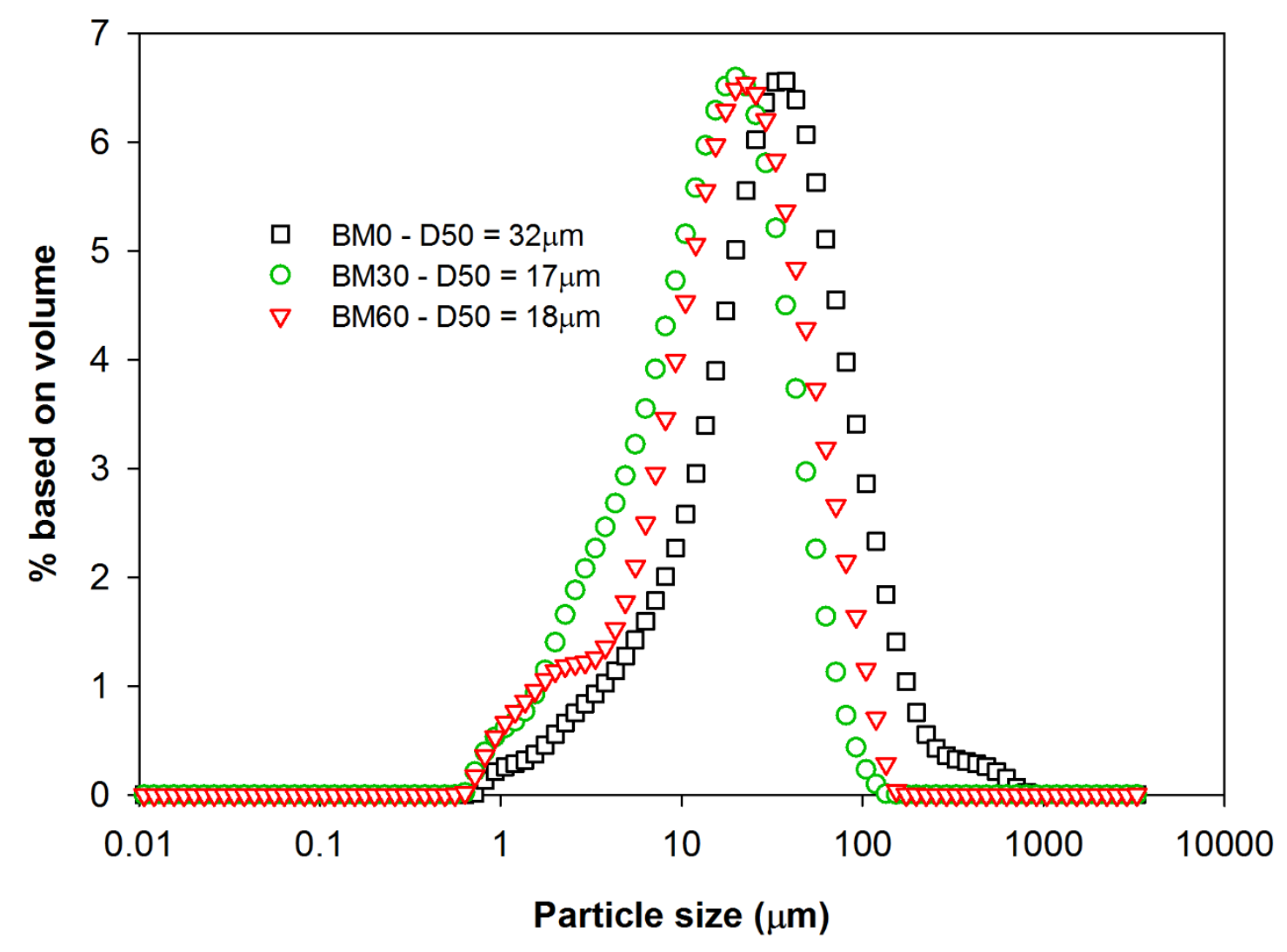


Figure 2

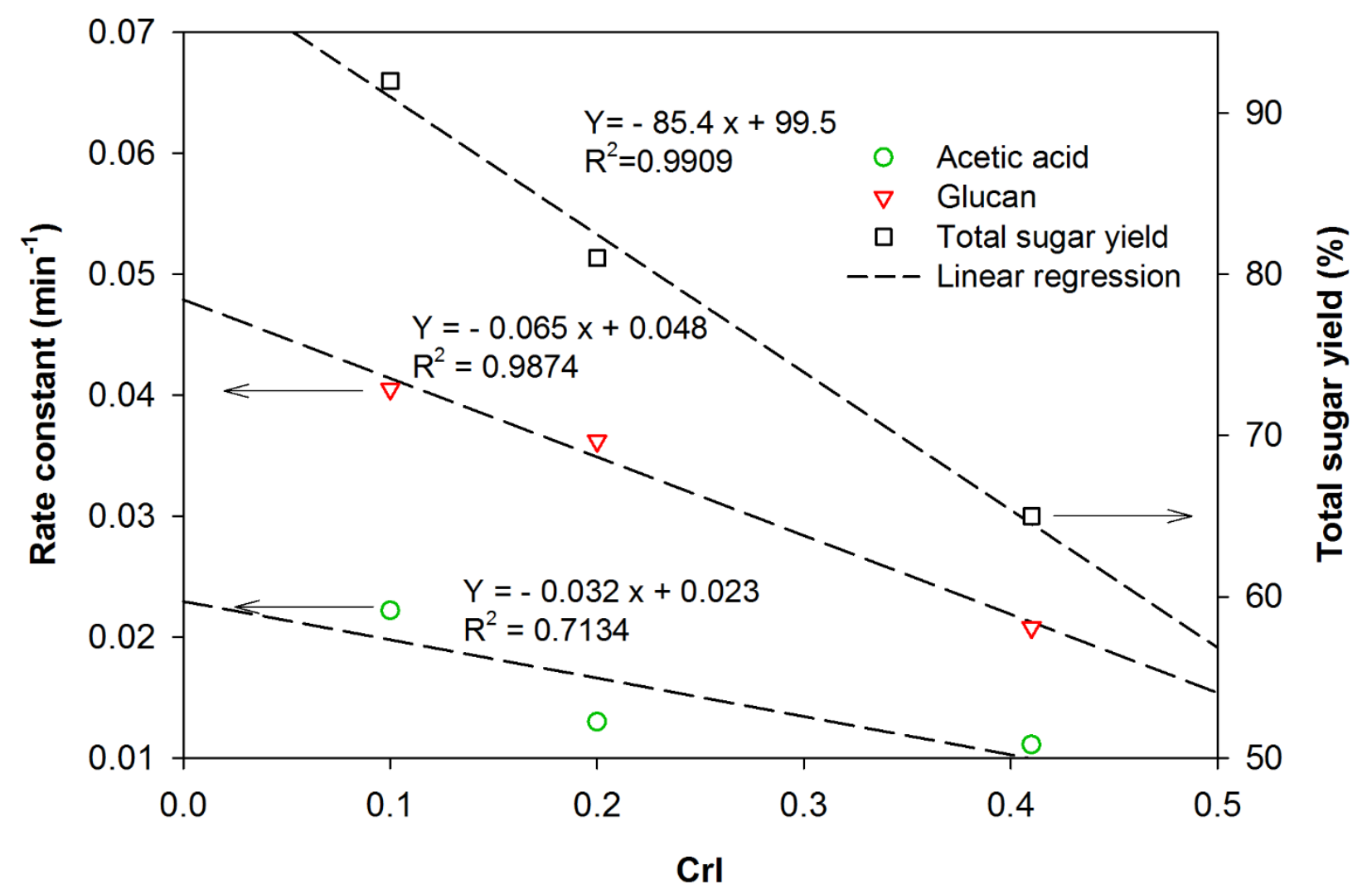

